The University of Maine

\title{
DigitalCommons@UMaine
}

Marine Sciences Faculty Scholarship

School of Marine Sciences

4-24-2007

\section{Size-Fractionated Nitrogen Uptake Measurements in the Equatorial Pacific and Confirmation of the Low Si-High-Nitrate Low-Chlorophyll Condition}

\author{
R. C. Dugdale \\ F. P. Wilkerson \\ Fei Chai \\ University of Maine - Main, fchai@maine.edu \\ R. Feely
}

Follow this and additional works at: https://digitalcommons.library.umaine.edu/sms_facpub

\section{Repository Citation}

Dugdale, R. C.; Wilkerson, F. P.; Chai, Fei; and Feely, R., "Size-Fractionated Nitrogen Uptake Measurements in the Equatorial Pacific and Confirmation of the Low Si-High-Nitrate Low-Chlorophyll Condition" (2007). Marine Sciences Faculty Scholarship. 122.

https://digitalcommons.library.umaine.edu/sms_facpub/122 


\title{
Size-fractionated nitrogen uptake measurements in the equatorial Pacific and confirmation of the low Si-high-nitrate low-chlorophyll condition
}

\author{
Richard C. Dugdale, ${ }^{1}$ Frances P. Wilkerson, ${ }^{1}$ Fei Chai, ${ }^{2}$ and Richard Feely ${ }^{3}$ \\ Received 17 March 2006; revised 5 September 2006; accepted 22 December 2006; published 24 April 2007.
}

[1] The equatorial Pacific Ocean is the largest natural source of $\mathrm{CO}_{2}$ to the atmosphere, and it significantly impacts the global carbon cycle. Much of the large flux of upwelled $\mathrm{CO}_{2}$ to the atmosphere is due to incomplete use of the available nitrate $\left(\mathrm{NO}_{3}\right)$ and low net productivity. This high-nutrient low-chlorophyll (HNLC) condition of the equatorial upwelling zone (EUZ) has been interpreted from modeling efforts to be due to low levels of silicate $\left(\mathrm{Si}(\mathrm{OH})_{4}\right)$ that limit the new production of diatoms. These ideas were incorporated into an ecosystem model, CoSINE. This model predicted production by the larger phytoplankton and the picoplankton and effects on air-sea $\mathrm{CO}_{2}$ fluxes in the Pacific Ocean. However, there were no size-fractionated rates available for verification. Here we report the first size-fractionated new and regenerated production rates (obtained with ${ }^{15} \mathrm{~N}-\mathrm{NO}_{3}$ and ${ }^{15} \mathrm{~N}-\mathrm{NH}_{4}$ incubations) for the EUZ with the objective of validating the conceptual basis and functioning of the CoSINE model. Specifically, the larger phytoplankton (with cell diameters $>5 \mu \mathrm{m}$ ) had greater rates of new production and higher f-ratios (i.e., the proportion of $\mathrm{NO}_{3}$ to the sum of $\mathrm{NO}_{3}$ and $\mathrm{NH}_{4}$ uptake) than the picoplankton that had high rates of $\mathrm{NH}_{4}$ uptake and low f-ratios. The way that the larger primary producers are regulated in the EUZ is discussed using a continuous chemostat approach. This combines control of $\mathrm{Si}(\mathrm{OH})_{4}$ production by supply rate (bottom-up) and control of growth rate (or dilution) by grazing (top-down control).

Citation: Dugdale, R. C., F. P. Wilkerson, F. Chai, and R. Feely (2007), Size-fractionated nitrogen uptake measurements in the equatorial Pacific and confirmation of the low Si-high-nitrate low-chlorophyll condition, Global Biogeochem. Cycles, 21, GB2005, doi:10.1029/2006GB002722.

\section{Introduction}

[2] The equatorial Pacific, extending from the coast of South America to Indonesia, possesses the largest single upwelling system in the world ocean. It has two characteristics that have focused the attention of oceanographers and atmospheric scientists. First the region is the largest source of $\mathrm{CO}_{2}$ flux from the ocean to the atmosphere [Feely et al., 2002; Takahashi et al., 2002] and second, the presence of primary nutrients at the surface along with relatively low chlorophyll concentrations have led to its designation as an HNLC (high-nitrate low-chlorophyll) region [Dugdale and Wilkerson, 1998]. The importance of the region to understanding the $\mathrm{CO}_{2}$ balance between the ocean and atmosphere has led to the question "why isn't the equator greener," and resulted in a series of major oceanographic cruises listed by Feely et al. [2002] and Le Borgne et al. [2002a].

\footnotetext{
${ }^{1}$ Romberg Tiburon Center, San Francisco State University, Tiburon, California, USA.

${ }^{2}$ School of Marine Science, University of Maine, Orono, Maine, USA.

${ }^{3}$ Pacific Marine Environmental Laboratory, National Oceanographic and Atmospheric Administration, Seattle, Washington, USA.

Copyright 2007 by the American Geophysical Union. 0886-6236/07/2006GB002722
}

[3] One hypothesis to explain the low biomass and high $\mathrm{pCO}_{2}$ at the equator was that the phytoplankton population was in a slow growth mode. This was refuted by the WEC88 cruise [Barber, 1992], in which growth rates of about $0.6 \mathrm{~d}^{-1}$ were measured [Cullen et al., 1992]. The phytoplankton in the equatorial upwelling zone (EUZ) are known to be dominated numerically by small cell-sized picoplankton [Mackey et al., 2002]. There is also a population of large cells that includes diatoms [Chavez et al., 1996; Iriarte and Fryxell, 1995; Bidigare and Ondrusek, 1996; Brown et al., 2003]. These observations led to another hypothesis that was proposed by Dugdale and Wilkerson [1998] that $\mathrm{Si}(\mathrm{OH})_{4}$ limitation was a causal factor. They observed that in many HNLC areas including the EUZ, $\mathrm{Si}(\mathrm{OH})_{4}$ concentrations were low compared to $\mathrm{NO}_{3}$ and might be linked to the low-chlorophyll condition [Dugdale et al., 1995]. Ku et al. [1995] using $\mathrm{Ra}^{228}$ as a tracer reported a low flux of $\mathrm{Si}(\mathrm{OH})_{4}$ compared to $\mathrm{NO}_{3}$ in the EUZ and suggested the region would be $\mathrm{Si}(\mathrm{OH})_{4}$-limited for diatoms. Profiles of $\mathrm{Si}(\mathrm{OH})_{4}$ and $\mathrm{NO}_{3}$ with depth at $140^{\circ} \mathrm{W}$ [Dugdale et al., 2002] showed relatively less $\mathrm{Si}(\mathrm{OH})_{4}$ compared to $\mathrm{NO}_{3}$ at source water depths, $(<200 \mathrm{~m}$, up to the surface). Plots of $\mathrm{NO}_{3}$ versus $\mathrm{Si}(\mathrm{OH})_{4}$ for the upper $200 \mathrm{~m}$ at $140^{\circ} \mathrm{W}$ showed a linear relationship with a $\mathrm{NO}_{3}$ intercept suggesting the possibility that most or all $\mathrm{NO}_{3}$ 
consumption was related to $\mathrm{Si}(\mathrm{OH})_{4}$ consumption, i.e., by diatom activity [Dugdale and Wilkerson, 1998]. However, from WEC 88 results obtained at $150^{\circ} \mathrm{W}$, most inorganic nitrogen taken up by the total phytoplankton population was $\mathrm{NH}_{4}$, indicated by low f-ratios (i.e., the proportion of $\mathrm{NO}_{3}$ to the sum of $\mathrm{NO}_{3}$ and $\mathrm{NH}_{4}$ uptake) [Dugdale et al., 1992].

[4] These observations, of likely $\mathrm{Si}(\mathrm{OH})_{4}$ limitation of diatoms, high growth rates, and high proportion of $\mathrm{NH}_{4}$ uptake, led to development of a biological model for the EUZ employing two functional groups of phytoplankton [Dugdale and Wilkerson, 1998], the larger sized phytoplankton, mostly diatoms and the smaller picoplankton feeding into a microbial loop. All $\mathrm{NO}_{3}$ uptake was ascribed to diatoms. $\mathrm{NH}_{4}$ produced by grazing on diatoms was taken up by the picoplankton and recycled by the microbial loop [Dugdale and Wilkerson, 1998]. Although no $\mathrm{Si}(\mathrm{OH})_{4}$ uptake data were available for the EUZ at the time the model was put forward, $\mathrm{Si}(\mathrm{OH})_{4}$ uptake kinetics were extrapolated from $\mathrm{NO}_{3}$ uptake kinetics for diatoms. These, and published values for the EUZ diatom population size [Bidigare and Ondrusek, 1996] were used in the model. Calculations showed that the excess $\mathrm{CO}_{2}$ at the surface was the result of diatoms being the exclusive users of $\mathrm{NO}_{3}$. The model suggested that the EUZ productivity system was closely akin to the chemostat system described by Frost and Franzen [1992].

[5] As an activity of the Synthesis and Modeling Program of the JGOFS [Le Borgne et al., 2002a], a one-dimensional model of the EUZ ecosystem was constructed melding the biological model based upon $\mathrm{Si}(\mathrm{OH})_{4}$ and two functional phytoplankton groups [Dugdale and Wilkerson, 1998] with the nitrogen based model of Chai et al. [1996]. The resulting model [Chai et al., 2002] given the name CoSINE (Carbon, Silicon, Nitrogen Ecosystem) was more flexible, allowing use of two forms of nitrogen $\left(\mathrm{NO}_{3}\right.$ and $\left.\mathrm{NH}_{4}\right)$ by both functional phytoplankton groups (diatoms and picoplankton) and including a fixed Fe effect on photosynthesis. One experiment made with the model was to increase the concentration of $\mathrm{Si}(\mathrm{OH})_{4}$ in the upwelling source waters while holding the $\mathrm{NO}_{3}$ concentration constant [Dugdale et al., 2002]. This showed a two phase response [Dugdale et al., 2004]. The initial response from low to intermediate concentrations of $\mathrm{Si}(\mathrm{OH})_{4}$, termed Phase 1, resulted in an increase in diatoms and a decrease in the dominant size class, the picoplankton, with accompanying increases in surface nutrient concentrations and $\mathrm{TCO}_{2}$. When $\mathrm{Si}(\mathrm{OH})_{4}$ was further increased (from $7.5 \mu \mathrm{M}$ to $15 \mu \mathrm{M}$ ), Phase 2 resulted with continuing increase in diatom biomass but a decrease in surface $\mathrm{TCO}_{2}$. These two phases represent two extremes: at the lowest $\mathrm{Si}(\mathrm{OH})_{4}$ concentrations the system is dominated by picoplankton and at the highest $\mathrm{Si}(\mathrm{OH})_{4}$ concentrations by diatoms. At each extreme, upwelled $\mathrm{CO}_{2}$ is fully incorporated into the phytoplankton. At intermediate $\mathrm{Si}(\mathrm{OH})_{4}$ concentrations, diatom populations are not sufficiently large to deplete all upwelled $\mathrm{CO}_{2}$ but are large enough to outcompete picoplankton biomass and their use of $\mathrm{CO}_{2}$.

[6] Such predictions of variables and functions from the 1-D CoSINE model could not be verified when the model was developed owing to insufficient data on rate processes for the EUZ. Specifically, the uptake of $\mathrm{NO}_{3}, \mathrm{NH}_{4}$ and $\mathrm{Si}(\mathrm{OH})_{4}$ by the larger cells compared to the smaller picoplankton (non-Si(OH) $)_{4}$ users) had not been reported for the EUZ. Similarly, the uptake kinetics for $\mathrm{Si}(\mathrm{OH})_{4}$ were only inferred from $\mathrm{NO}_{3}$ uptake kinetics. The relative biomass (as particulate nitrogen, $\mathrm{PON}$ ) of the two groups of phytoplankton and the biomass of the diatoms as biogenic silica (BSi) was unknown. Also unknown was the regeneration rate of $\mathrm{Si}(\mathrm{OH})_{4}$ in the euphotic zone. Scientists, funded by the NSF Biocomplexity Program, made two cruises to the EUZ, in December 2004 (EB04) and September 2005 (EB05) with the goal of measuring the missing variables and functions. The field study had the specific objective of validating the conceptual basis and functioning of the CoSINE model, with $\mathrm{Si}(\mathrm{OH})_{4}$ playing a leading regulatory role. Here we report results from the December 2004 cruise to evaluate whether the larger cell-sized phytoplankton dominate EUZ new production and how changes in $\mathrm{Si}(\mathrm{OH})_{4}, \mathrm{NO}_{3}$ and $\mathrm{TCO}_{2}$ result in the HNLC condition; all described in a predictive way by the CoSINE model.

\section{Methods}

[7] Data described here were obtained during Cruise EB04 aboard the R/V Roger Revelle between 10 and 28 December 2004. The cruise sampled a north-south $\left(4^{\circ} \mathrm{N}-4^{\circ} \mathrm{S}\right)$ transect at $110^{\circ} \mathrm{W}$ and then a zonal section from $110^{\circ} \mathrm{W}$ to $140^{\circ} \mathrm{W}$ along the equator. Seawater was collected using acid-cleaned 10-L PVC Niskin bottles with Teflon coated springs mounted on an instrumented rosette. Water samples from throughout the water column were collected for $\mathrm{NO}_{3}$ (measured as $\mathrm{NO}_{3}$ plus $\mathrm{NO}_{2}$ with consistently low $\left.\mathrm{NO}_{2}\right)$ and $\mathrm{Si}(\mathrm{OH})_{4}$ analyses in $20 \mathrm{~mL}$ polypropylene bottles and held at $4{ }^{\circ} \mathrm{C}$ until analysis (within $12-24$ hours) with a Bran and Luebbe AutoAnalyzer II $\left(\mathrm{NO}_{3}\right.$ according to Whitledge et al. [1981] and $\mathrm{Si}(\mathrm{OH})_{4}$ using Bran Luebbe AutoAnalyzer Applications [1999]). For ammonium $\left(\mathrm{NH}_{4}\right)$ analyses, water was sampled into $60 \mathrm{~mL}$ polycarbonate centrifuge tubes and treated with phenol reagent [Solorzano, 1969] on shipboard and held at $4^{\circ} \mathrm{C}$ until analysis using a Hewlett Packard Model 8452A diode array spectrophotometer equipped with a $10 \mathrm{~cm}$ cuvette. $\mathrm{TCO}_{2}$ samples were analyzed by R. Feely (personal communication, 2005) using coulometric titration (UIC, Inc.).

[8] For ${ }^{15} \mathrm{~N}$ uptake measurements, water was sampled into acid-washed 2-L polycarbonate bottles at depths equivalent to where there was 52,13 , and $0.8 \%$ of surface irradiance. These bottles were inoculated with either $\mathrm{K}^{15} \mathrm{NO}_{3}$ or ${ }^{15} \mathrm{NH}_{4} \mathrm{Cl}$ (both at 99 atom $\%{ }^{15} \mathrm{~N}$ ), at concentrations equivalent to $5-10 \%$ of ambient concentration; i.e., trace enrichments. The bottles were then placed into an ondeck water-cooled incubator under screening to simulate collection site in situ temperature and irradiance conditions, and incubated for six daylight hours around local noon. Incubations were terminated by filtration onto precombusted $\left(450^{\circ} \mathrm{C}\right.$ for four hours) Whatman $25 \mathrm{~mm} \mathrm{GF} / \mathrm{F}$ filters for uptake rates by the entire phytoplankton community (filters have nominal pore size of $0.7 \mu \mathrm{m}$ ) or onto $25 \mathrm{~mm}$ diameter Poretics silver filters with $5 \mu \mathrm{m}$ pore size that sample the larger phytoplankton cells, with cell diameters 
a

b

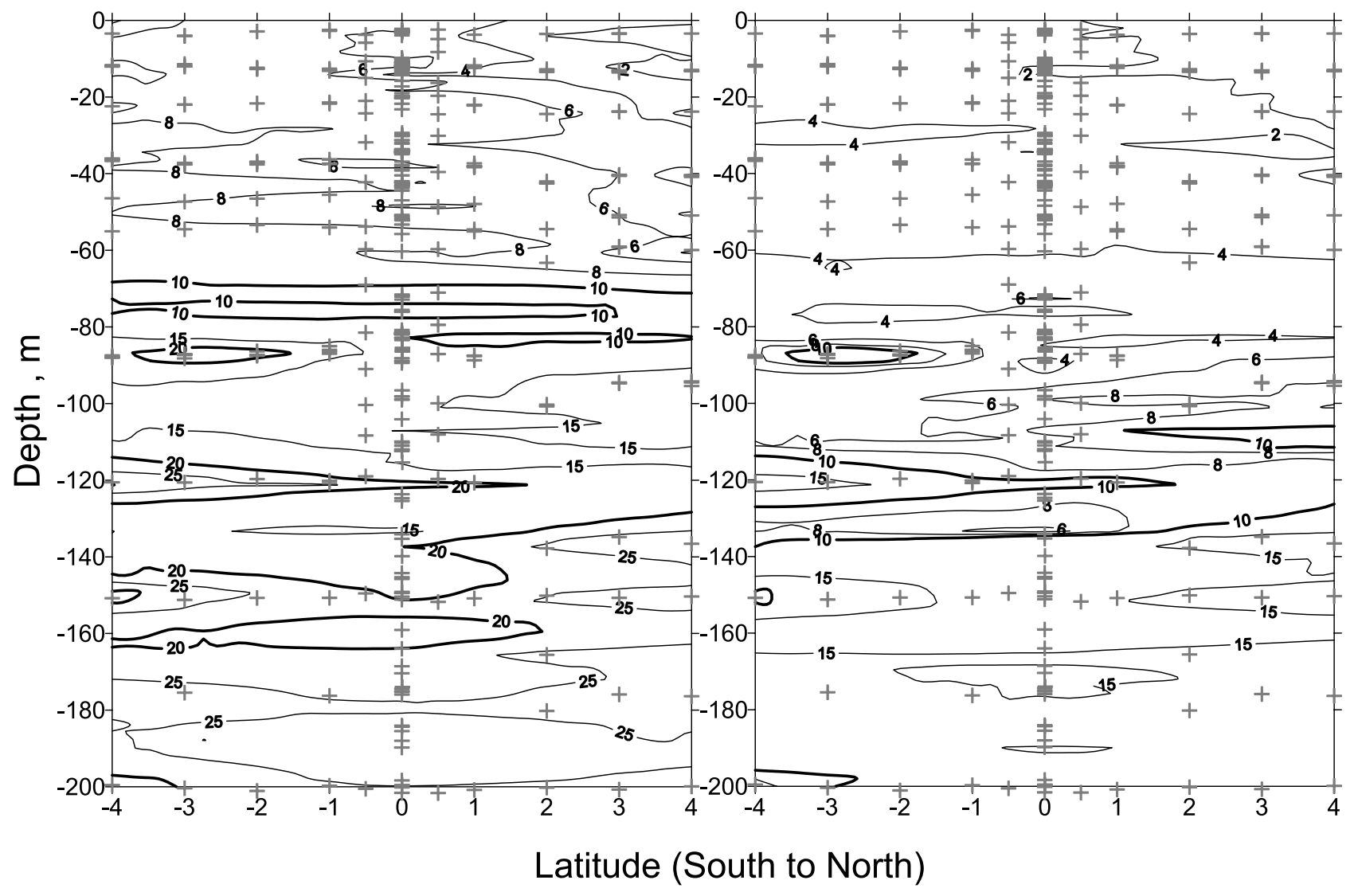

Figure 1. Meridional section from $4^{\circ} \mathrm{S}$ to $4^{\circ} \mathrm{N}$, at $110^{\circ} \mathrm{W}$ sampled during $\mathrm{EB} 04$ : (a) $\mathrm{NO}_{3}, \mu \mathrm{M}$; (b) $\mathrm{Si}(\mathrm{OH})_{4}, \mu \mathrm{M}$.

$>5 \mu \mathrm{m}$. All filters were kept frozen until analysis when they were dried $\left(<60^{\circ} \mathrm{C}\right.$ for $\left.>24 \mathrm{hr}\right)$ and analyzed for ${ }^{15} \mathrm{~N}$ enrichment and PON with a PDZ Europa 20/20 mass spectrometer system [Wilkerson and Dugdale, 1992]. The transport $(\rho)$ and specific uptake rates (V) were calculated according to Dugdale and Wilkerson [1986]. Uptake by the $<5 \mu \mathrm{m}$ cells, termed picoplankton here, was obtained by subtracting the data for the $>5 \mu \mathrm{m}$ cells from that measured using $\mathrm{GF} / \mathrm{F}$ filters.

\section{Results}

\subsection{Meridional Section at $110^{\circ} \mathrm{W}$}

[9] The nutrient concentrations measured along the section across the equator at $110^{\circ} \mathrm{W}$ showed increasing values going from north to south at depths less than $60 \mathrm{~m}$ (Figures 1a and $1 \mathrm{~b}$ ) with lower $\mathrm{Si}(\mathrm{OH})_{4}$ compared to $\mathrm{NO}_{3}$ concentrations at all depths characteristic of the equatorial system. The lack of obvious upward slopes below $60 \mathrm{~m}$ suggests these gradients were due to horizontal advection, perhaps from tropical instability wave activity.

[10] $\mathrm{NO}_{3}$ uptake rates by large and small cell sized phytoplankton collected from near surface (equivalent to the $52 \%$ light penetration depth) and incubated with $52 \%$ of surface irradiance (Figure 2), showed a general increase in uptake by all cells toward the north, with a decrease between $3^{\circ} \mathrm{N}$ and $4^{\circ} \mathrm{N}$ (the more oligotrophic station). The same trend was shown by the small sized cells with lower values toward the south, while uptake by the cells $>5 \mu \mathrm{m}$ was relatively constant at $0.0025 \mu \mathrm{mol} \mathrm{L}^{-1} \mathrm{~h}^{-1}$, except for the low value at $4^{\circ} \mathrm{N}$. The higher variability in the small fraction values is probably the result of the fractionation procedure used, i.e., subtracting the values obtained using $5 \mu \mathrm{m}$ filters from those using $\mathrm{GF} / \mathrm{F}$ filters. $\mathrm{NO}_{3}$ uptake by the larger phytoplankton was greater than by the picoplankton throughout the transect. The contribution of the larger cells to total $\mathrm{NO}_{3}$ uptake (Figure $2 \mathrm{~b}$ ) showed how they dominated uptake by $>90 \%$ at $2^{\circ}$ to $4^{\circ} \mathrm{S}$. This dropped to $50 \%$ at the north end of the section.

[11] $\mathrm{NH}_{4}$ uptake rates showed similar changes (Figure 3a) with a general trend for increasing rates by the total population and the smaller cells, going from $4^{\circ} \mathrm{S}$ to $4^{\circ} \mathrm{N}$. $\mathrm{NH}_{4}$ uptake by the larger cells was relatively constant at all latitudes at $0.003 \mu \mathrm{mol} \mathrm{L}{ }^{-1} \mathrm{~h}^{-1}$. Rates of picoplankton uptake of $\mathrm{NH}_{4}$ were similar to or greater than rates measured for the larger cells. The f-ratio (Figure $3 \mathrm{~b}$ ) was greater for the larger cells and relatively constant $(\sim 0.5)$. The f-ratio by the smaller cells $(<5 \mu \mathrm{m})$ increased from south to north with values of 0.2 or less at $3^{\circ} \mathrm{S}$ to $4^{\circ} \mathrm{S}$, indicating mostly use of $\mathrm{NH}_{4}$. These data show clearly the dominance of 


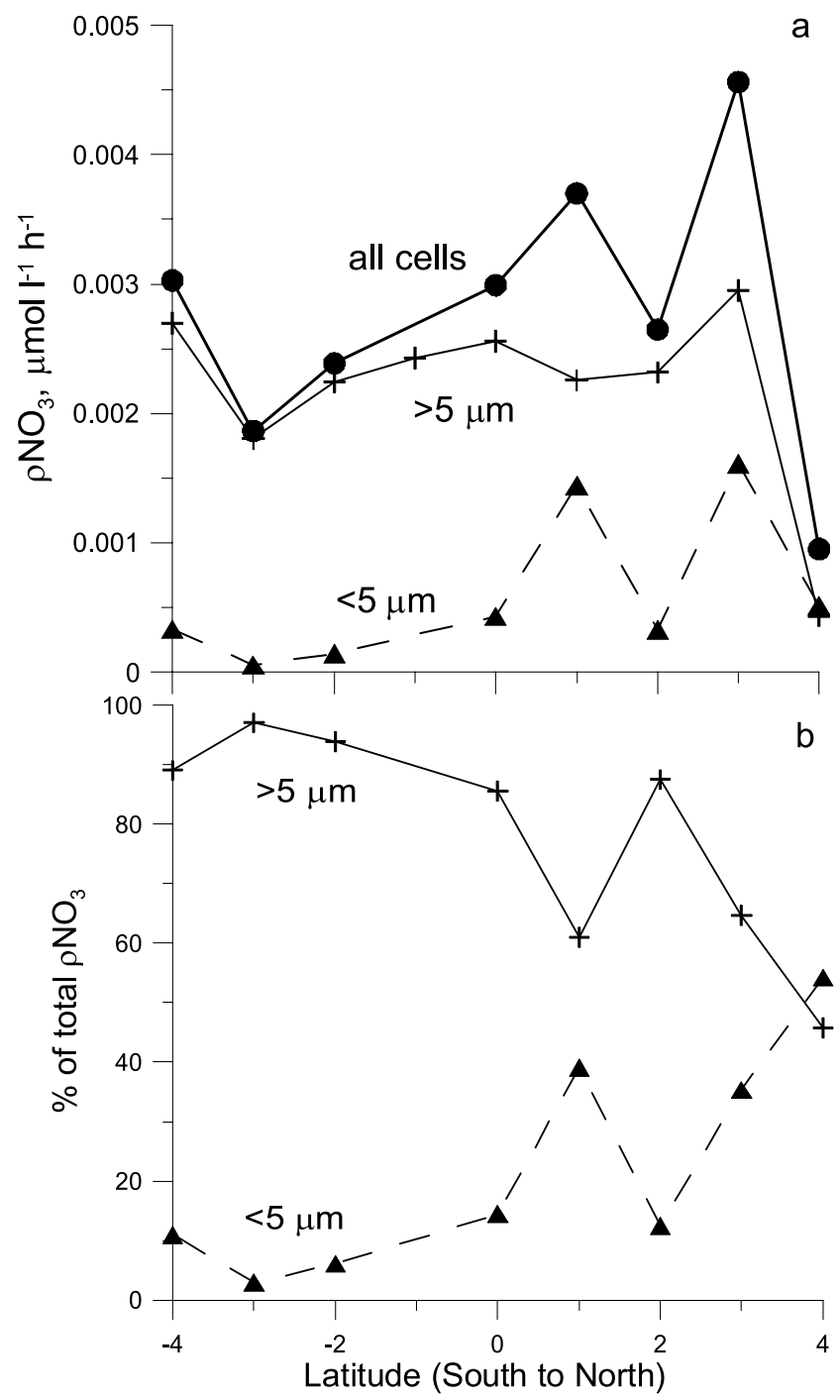

Figure 2. Meridional section from $4^{\circ} \mathrm{S}$ to $4^{\circ} \mathrm{N}$ at $110^{\circ} \mathrm{W}$ sampled during EB04: (a) near surface $\rho \mathrm{NO}_{3}$, $\mu \mathrm{mol} \mathrm{L}^{-1} \mathrm{~h}^{-1}$ by phytoplankton cells $>5 \mu \mathrm{m}$ and $<5 \mu \mathrm{m}$ diameter; (b) percent contribution by the two size fractions to total $\rho \mathrm{NO}_{3}$ uptake.

the larger celled population in taking up $\mathrm{NO}_{3}$ and the dependence of the smaller picoplankton on recycled nitrogen, $\mathrm{NH}_{4}$.

\subsection{Zonal Section From $140^{\circ} \mathrm{W}$ to $110^{\circ} \mathrm{W}$}

[12] Although the $20^{\circ} \mathrm{C}$ isotherm (not shown) shallowed from $145 \mathrm{~m}$ at $140^{\circ} \mathrm{W}$ to $100 \mathrm{~m}$ at $110^{\circ} \mathrm{W}$, there was only a small increase in $\mathrm{NO}_{3}$ concentration at depth (e.g., at $140 \mathrm{~m}$, Figure 4a). The $\mathrm{Si}(\mathrm{OH})_{4}$ gradient at the same depth (Figure 4b) was essentially flat. Changes in both nutrients near the surface were due primarily to biological processes, including uptake and regeneration, rather than to physical processes. Three vertical depths (equivalent to the $52 \%$. $13 \%$ and $0.8 \%$ light penetration depths) were sampled at the equator for size-fractionated nitrogen uptake and showed decreasing $\mathrm{NO}_{3}$ uptake with depth (Figures $5 \mathrm{a}, 5 \mathrm{~b}$, and $5 \mathrm{c}$ ). Uptake at 52\% and $13 \%$ light penetration depths had greater $\mathrm{NO}_{3}$ uptake by the larger cells $(>5 \mu \mathrm{m})$ than the picoplankton, with values reaching $\sim 0.01 \mu \mathrm{mol} \mathrm{L}^{-1} \mathrm{~h}^{-1}$ at $140^{\circ} \mathrm{W}$, but decreasing to the east. $\mathrm{NO}_{3}$ uptake at the $0.8 \%$ light penetration depth by both size fractions was very low $\left(<0.001 \mu \mathrm{mol} \mathrm{L}{ }^{-1} \mathrm{~h}^{-1}\right)$ with slightly higher uptake by the picoplankton. The f-ratios (Figure 6) were greater throughout the transect for the larger phytoplankton indicating their dominant role in new production with f-ratios $>0.5$, increasing going west with the highest value of 0.8 at to $140^{\circ} \mathrm{W}$. The f-ratios for the picoplankton throughout the transect were $<0.5$ indicating that $\mathrm{NH}_{4}$ is their major source of nitrogen compared to $\mathrm{NO}_{3}$.

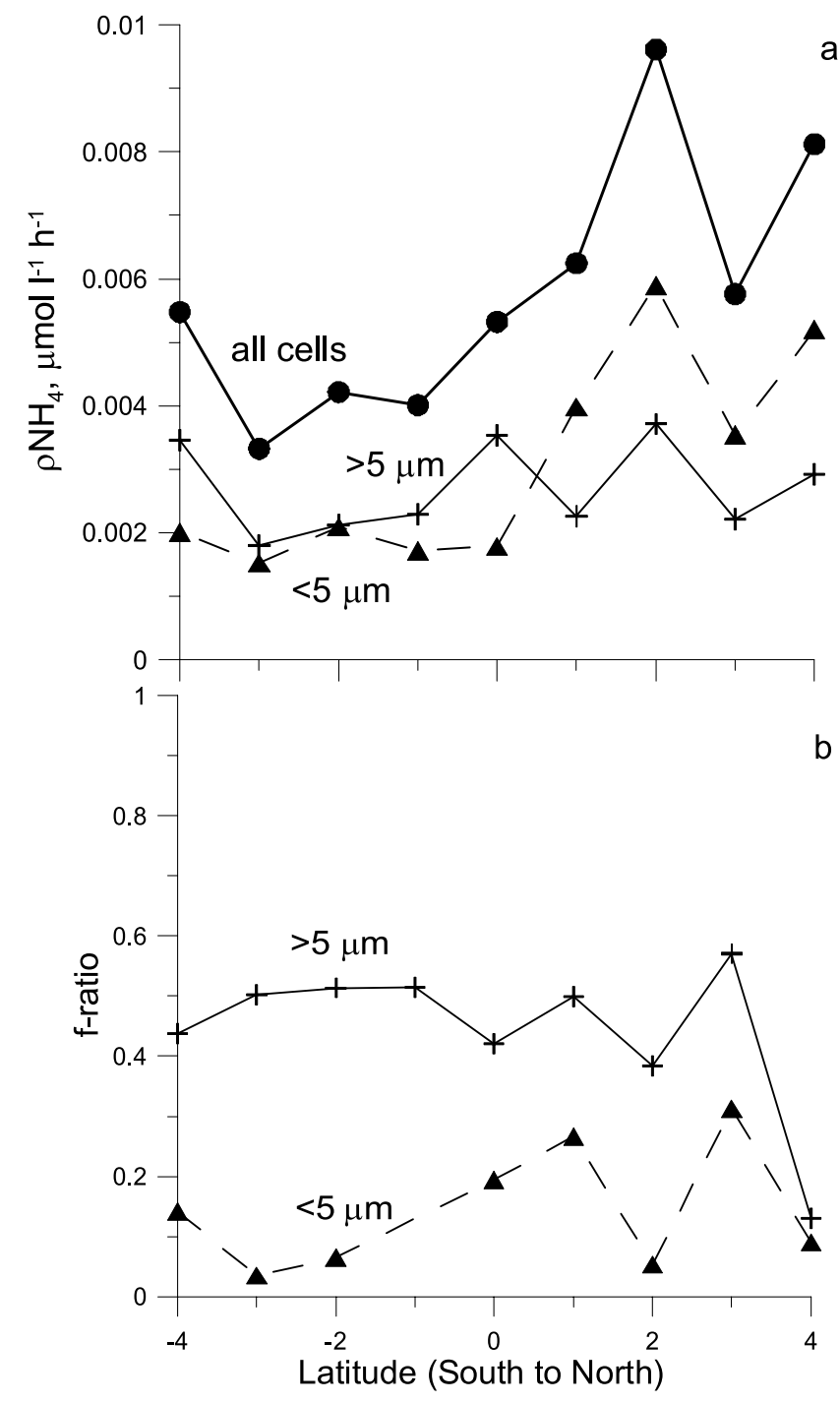

Figure 3. Meridional section from $4^{\circ} \mathrm{S}$ to $4^{\circ} \mathrm{N}$ at $110^{\circ} \mathrm{W}$ sampled during EB04: (a) near-surface $\rho \mathrm{NH}_{4}, \mu \mathrm{mol} \mathrm{L}^{-1} \mathrm{~h}^{-1}$ by phytoplankton cells $>5 \mu \mathrm{m}$ and $<5 \mu \mathrm{m}$ diameter; (b) f-ratio of the two size fractions. 
a

b

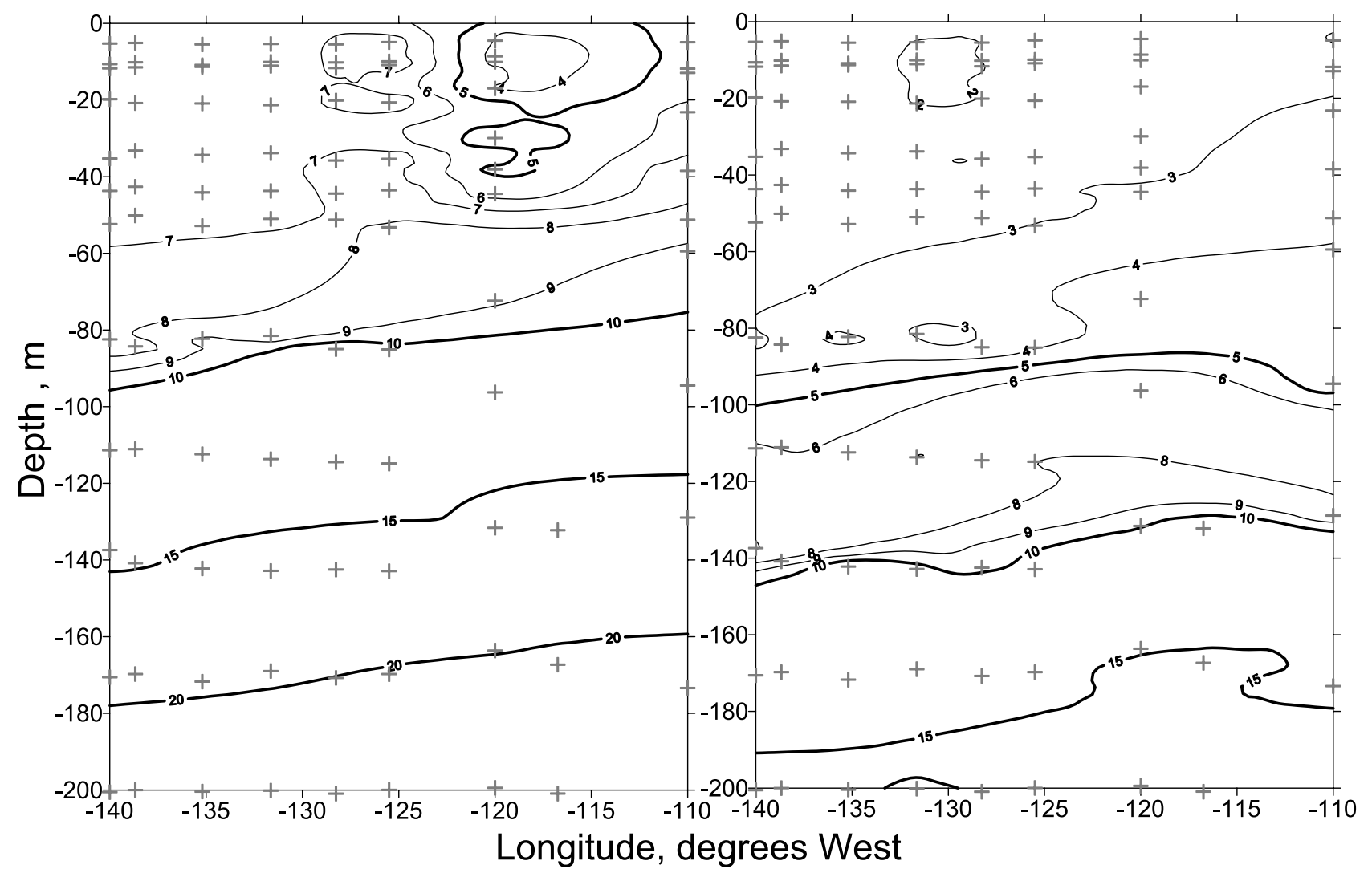

Figure 4. Zonal section from $140^{\circ} \mathrm{W}$ to $110^{\circ} \mathrm{W}$, along the equator sampled during EB04: (a) $\mathrm{NO}_{3}, \mu \mathrm{M}_{\text {; }}$ (b) $\mathrm{Si}(\mathrm{OH})_{4}, \mu \mathrm{M}$.

\subsection{Comparison With CoSINE Model Predictions}

[13] The mean surface zonal data from EB04 (from $140^{\circ} \mathrm{W}$ to $110^{\circ} \mathrm{W}$ along $0^{\circ}$ ) is compared with predictions of the 1-D CoSINE model in Table 1. To make predictions from the model of surface features, source concentrations from below the photic zone of $\mathrm{Si}(\mathrm{OH})_{4}(7.5 \mu \mathrm{M})$ and $\mathrm{NO}_{3}$ $(12 \mu \mathrm{M})$ termed "intermediate" [Dugdale et al., 2002] were used. During EB04 the mean zonal $\mathrm{Si}(\mathrm{OH})_{4}$ and $\mathrm{NO}_{3}$ concentrations at the $0.1 \%$ light level (mean depth $114 \mathrm{~m}$ ) were very close $\left(\mathrm{Si}(\mathrm{OH})_{4}=7.8 \mu \mathrm{M}\right.$ and $\left.\mathrm{NO}_{3}=14.1 \mu \mathrm{M}\right)$ validating this comparison. For both the model and data, the surface biomass of larger cells is less than that of the picoplankton $(<5 \mu \mathrm{m})$, but both populations (measured as PON) are greater than predicted by the model. In EB04, $\mathrm{NO}_{3}$ uptake by the larger cells was higher than predicted by the model; but was lower than predicted for the picoplankton. The f-ratio measured for the $>5 \mu \mathrm{m}$ cells in EB04 $(0.60)$ was identical to the modeled value, but that measured for the picoplankton $(0.13)$ was about half of the predicted value $(0.22)$.

[14] In addition to comparing mean values, the patterns of change of different variables (e.g., nutrients or nitrogen uptake) predicted by the model can be compared with those measured during EB04. The modeled pattern of steep increases in surface $\mathrm{NO}_{3}$ and $\mathrm{TCO}_{2}$ but smaller changes in surface $\mathrm{Si}(\mathrm{OH})_{4}$ resulting from increased source $\mathrm{Si}(\mathrm{OH})_{4}$ (Figure 7a) was observed in the surface plots of these same variables for the EB04 $110^{\circ} \mathrm{W}$ section (Figure $7 b$ ). Surface $\mathrm{NO}_{3}$ and $\mathrm{TCO}_{2}$ for both the $110^{\circ} \mathrm{W}$ and the zonal EB04 sections (Figure 7c) confirm the predicted pattern of changes in surface $\mathrm{TCO}_{2}$ related to changes in surface $\mathrm{NO}_{3}$. The regression lines (zonal and meridional, Figure $7 \mathrm{c}$ ) show that drawdown of source concentrations of $\mathrm{NO}_{3}$ and $\mathrm{TCO}_{2}$ are related linearly. On EB04 the mean concentrations for the $0.8 \%$ light penetration depth $(84.5 \mathrm{~m})$ were $\mathrm{NO}_{3}=9.48 \mu \mathrm{M}, \mathrm{TCO}_{2}=2058.63 \mu \mathrm{M}$. Reductions from these values measured at the base of the euphotic zone to lower surface values, occur through phytoplankton uptake of $\mathrm{NO}_{3}$ (new production). The minimum values for surface $\mathrm{TCO}_{2}$ and $\mathrm{NO}_{3}$ on the zonal section (along the equator) are due to the lack of sufficient $\mathrm{Si}(\mathrm{OH})_{4}$ in the source water to allow diatoms to take up all of the $\mathrm{NO}_{3}$ and associated $\mathrm{TCO}_{2}$. The full range of changes in $\mathrm{TCO}_{2}$ that can be attributed to phytoplankton is shown by the $110^{\circ} \mathrm{W}$ regression line (Figure 7c). The slopes of the regression lines of $\mathrm{TCO}_{2}$ versus $\mathrm{NO}_{3}$ are 13.03 and 12.76, well above the Redfield ratio of 6.6:1. This suggests that the major $\mathrm{NO}_{3}$-using phytoplankton fraction (i.e., $>5 \mu \mathrm{m}$ cells) are unusually rich in carbon. The EB04 data is consistent with this suggestion as the measured mean ratio of POC:PON 


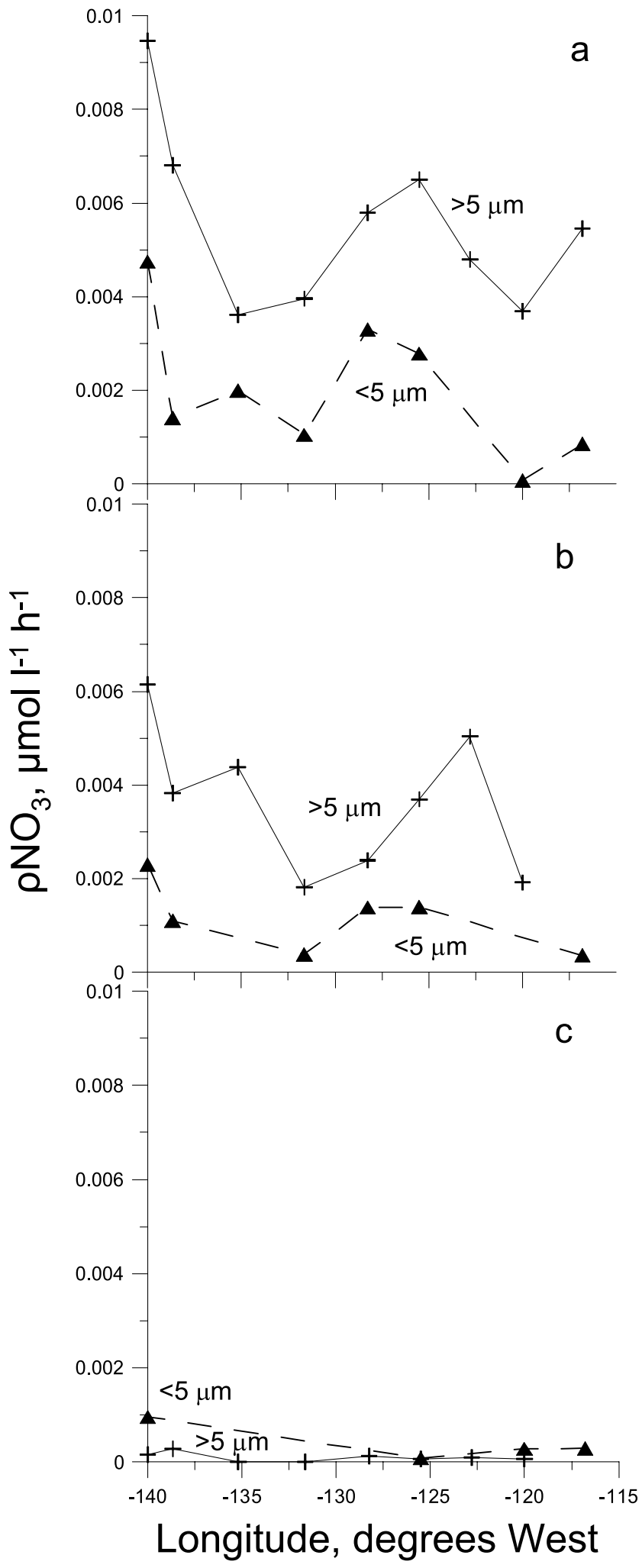

Figure 5. Zonal section of $\rho \mathrm{NO}_{3}, \mu \mathrm{mol} \mathrm{L}^{-1} \mathrm{~h}^{-1}$, by phytoplankton cells $>5 \mu \mathrm{m}$ and $<5 \mu \mathrm{m}$ from $140^{\circ} \mathrm{W}$ to $116.8^{\circ} \mathrm{W}$, along the equator sampled during EB04: (a) nearsurface (52\% light depth); (b) 13\% light depth; (c) $0.8 \%$ light depth. was 10.6 in the $>5 \mu \mathrm{m}$ size class (Table 1). The measured values of POC and PON in Table 1 include all material held by either GF/F or $5 \mu \mathrm{m}$ filters and so have some detrital material included in these estimates. Different proportions of detrital $\mathrm{C}$ and $\mathrm{N}$ would bias the estimate of the ratio of the two elements, but we have no way to estimate these proportions at the present time. The $>5 \mu \mathrm{m}$ fraction will also include heterotrophs. Brown et al. [2003] reported during EBENE that on average the heterotrophic biomass equaled that of the autotrophic biomass. Presence of a large heterotrophic population in our samples would tend to drive the ratio of POC:PON higher.

\section{Discussion}

[15] The data described here from EB04 of size-fractionated nitrogen uptake in the equatorial Pacific confirm the assumptions made by the CoSINE model. Most of the $\mathrm{NO}_{3}$ uptake (new production) is being carried out by the larger sized phytoplankton that display higher f-ratios, even though the biomass is dominated by the smaller picoplankton. In the model these larger cells are diatoms. Conversely, as assumed in the model and borne out by the data, the smaller picoplankton (here including cells $<5 \mu \mathrm{m}$ in diameter) have greater $\mathrm{NH}_{4}$ uptake and low $\mathrm{f}$-ratios. The data collected during EB04 also confirm some of the trends predicted by the model, that small changes in source $\mathrm{Si}(\mathrm{OH})_{4}$ in the upwelled water will result in greater impacts on surface $\mathrm{NO}_{3}$ and $\mathrm{TCO}_{2}$ than on surface $\mathrm{Si}(\mathrm{OH})_{4}$ (Figure $7 \mathrm{~b}$ ). The values used in the model for simulations (e.g., "intermediate" source value of $7.5 \mu \mathrm{M} \mathrm{Si}(\mathrm{OH})_{4}$ and $12 \mu \mathrm{M} \mathrm{NO} 3$ ) were also shown to be suitable, as they matched concentrations measured at depth along the equator during EB04. The observational results help support the original suggestion of Dugdale and Wilkerson [1998] that $\mathrm{NO}_{3}$ uptake in the EUZ is likely due to a diatom population whose size and productivity is limited by the low input of $\mathrm{Si}(\mathrm{OH})_{4}$ compared to $\mathrm{NO}_{3}$ from the equatorial undercurrent source water [Ku et al., 1995]. The remarkable stability of the eastern equatorial Pacific upwelling system may be conferred by $\mathrm{Si}(\mathrm{OH})_{4}$ limitation of diatom growth. The surface $\mathrm{Si}(\mathrm{OH})_{4}$ concentration reflects the value necessary to allow growth rates required to offset the loss rates, likely dominated by grazing processes. If $\mathrm{NO}_{3}$ is taken up primarily by the diatoms, and is present in source waters in excess of diatom requirements, unused amounts of both $\mathrm{NO}_{3}$ and associated $\mathrm{TCO}_{2}$ would remain at the surface, leading to a low $\mathrm{Si}-\mathrm{HNLC}$ region. In such a situation, the diatom portion of the system is functioning perfectly normally in a continuous culture mode.

[16] The CoSINE model was constructed as a $\mathrm{Si}(\mathrm{OH})_{4}$ limited continuous culture system akin to a chemostat, and this is probably why it simulates the equatorial Pacific productivity so well. In the model, the rate of $\mathrm{Si}(\mathrm{OH})_{4}$ uptake is a function of ambient $\mathrm{Si}(\mathrm{OH})_{4}$ concentration and parameterized through the Michaelis-Menten equation,

$$
\mathrm{V}_{\mathrm{Si}}=\mathrm{Vmax}_{\mathrm{Si}} * \mathrm{Si}(\mathrm{OH})_{4} /\left(\mathrm{Si}(\mathrm{OH})_{4}+\mathrm{K}_{\mathrm{Si}}\right),
$$

where $\mathrm{V}_{\mathrm{Si}}$ is the biomass specific uptake rate of $\mathrm{Si}(\mathrm{OH})_{4}$, $\mathrm{Vmax}_{\mathrm{Si}}$ is the biomass specific uptake rate of $\mathrm{Si}(\mathrm{OH})_{4}$ at the 


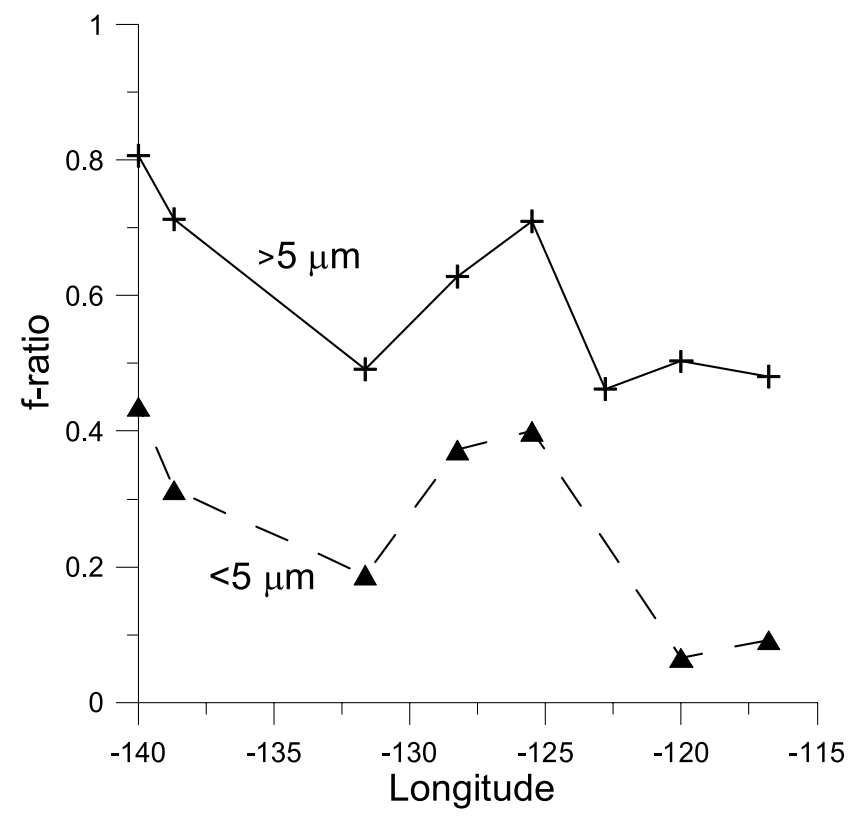

Figure 6. Zonal section of f-ratio of phytoplankton $>5 \mu \mathrm{m}$ and $<5 \mu \mathrm{m}$, from $140^{\circ} \mathrm{W}$ to $116.8^{\circ} \mathrm{W}$, along the equator sampled during EB04.

saturating substrate $\mathrm{Si}(\mathrm{OH})_{4}$ concentration, and $\mathrm{K}_{\mathrm{Si}}$ is the $\mathrm{Si}(\mathrm{OH})_{4}$ concentration at which $\mathrm{V}_{\mathrm{Si}}=1 / 2 \mathrm{Vmax}_{\mathrm{Si}}$. Since there were no published kinetic constants for $\mathrm{Si}(\mathrm{OH})_{4}$ uptake in the equatorial Pacific upwelling system when the CoSINE model was constructed, values were extrapolated from $\mathrm{NO}_{3}$ kinetics. The values used were $\operatorname{Vmax}_{\mathrm{Si}}=1.5 \mathrm{~d}^{-1}$ and $\mathrm{K}_{\mathrm{Si}}=3.0 \mu \mathrm{M}$. A reduction in $\mathrm{Vmax}_{\mathrm{Si}}$ to include an influence for $\mathrm{Fe}$ was included through photosynthetic parameters. The result was to predict ambient $\mathrm{Si}(\mathrm{OH})_{4}$ surface concentrations in the range of about $1-3 \mu \mathrm{M}$ which were observed during EB04 (mean surface $\mathrm{Si}(\mathrm{OH})_{4}$ concentration $=2.17 \mu \mathrm{M}$, Table 1). Subsequently, Leynaert et al. [2001] published Michaelis-Menten kinetics from the equatorial Pacific equator with $V_{\max } \mathrm{Si}$ of $1.25 \mathrm{~d}^{-1}$ (calculated from their hourly value multiplied by 24) and $\mathrm{K}_{\mathrm{Si}}=2.42 \mu \mathrm{M}$, both close to the values assumed for the CoSINE model. Both model and ecosystem appear to be regulating on $\mathrm{Si}(\mathrm{OH})_{4}$ at a concentration near the assumed and measured $\mathrm{K}_{\mathrm{si}}$ values. The ambient $\mathrm{Si}(\mathrm{OH})_{4}$ concentration is the operating point in this $\mathrm{Si}(\mathrm{OH})_{4}$ limited continuous culture system [Dugdale and Wilkerson, 1992] and is set by the loss rates, primarily grazing [Frost and Franzen, 1992]. The system should be understood as $\mathrm{Si}(\mathrm{OH})_{4}$ limited for diatoms from bottom up because the supply feed water is low in $\mathrm{Si}(\mathrm{OH})_{4}$ compared to $\mathrm{NO}_{3}$. The diatom growth rate is set from top down by loss rates due primarily to grazing and some sinking. The $\mathrm{Si}(\mathrm{OH})_{4}$ concentration at the operating point has important consequences. Together with the upwelling source concentration of $\mathrm{Si}(\mathrm{OH})_{4}$, and the depth of the euphotic zone or mixed layer, it sets the size of the diatom population (here defined as biogenic silica, BSi). This can be estimated from a reduced mass balance equation,

$$
\mathrm{BSi}=\left(\text { source } \mathrm{Si}(\mathrm{OH})_{4}-\text { operating point } \mathrm{Si}(\mathrm{OH})_{4}\right) / \mathrm{Z}_{\text {euphotic }} \text {. }
$$

[17] For the mean source and ambient concentrations during EB04 (Table 1), along with the depth of the mixed layer $(0.1 \% \mathrm{LPD})$,

$$
\mathrm{BSi}=(7.8-2.17) / 114=0.049 \mu \mathrm{mol} \mathrm{L}^{-1} .
$$

This compares with the predicted value from the CoSINE model $\left(0.089 \mu \mathrm{mol} \mathrm{L}{ }^{-1}\right.$ PON and BSi, Table 1 assuming BSi:PON of 1:1 [Brzezinski, 1985]).

[18] The close relationship of EB04 data with the CoSINE model indicates that regulation of the equatorial primary production system appears to be on $\mathrm{Si}(\mathrm{OH})_{4}$. However, the possibility of a secondary limitation or modulation of $\mathrm{Si}(\mathrm{OH})_{4}$ uptake by Fe may occur. Leynaert et al. [2004], using diatoms in culture showed the $\mathrm{Vmax}_{\mathrm{Si}}$ to vary with the concentration of Fe. The effect of trace metal deficiency on continuous culture conditions through control of Vmax was discussed by Dugdale [1967] in the context of molybdenum effects on nitrogen fixation. The concept is applicable to the role of $\mathrm{Fe}$ in a $\mathrm{Si}(\mathrm{OH})_{4}$ limited system such as the equatorial Pacific. The Leynaert et al. [2004] relationship between $\mathrm{Vmax}_{\mathrm{Si}}$ versus Fe was hyperbolic. This relationship can be used to calculate the effect Fe will have on the BSi. However, for simplicity, the relationship used here is linear, representing the initial slope of the hyperbola. The slope of the linear equation, $0.5 \mathrm{~h}^{-1} / \mathrm{nM} \mathrm{Fe}$ was calculated from the $\mathrm{Vmax}_{\mathrm{Si}}$ of Leynaert et al. [2001], $0.052 \mathrm{~h}^{-1}$, and the range of $\mathrm{Fe}$ concentrations observed in EB04, 0.05 to $1 \mathrm{nM}$ (C. Measures, personal communication, 2005). The expected effect of changes in Fe concentration can be

Table 1. CoSINE Model Predictions Based Upon a Source $\mathrm{Si}(\mathrm{OH})_{4}$ of $7.5 \mu \mathrm{M}$ Compared With Mean Values From EB04

\begin{tabular}{|c|c|c|c|}
\hline & $\begin{array}{c}\text { Concentration } \\
\text { or Rate }\end{array}$ & Model & EB04 \\
\hline \multirow[t]{2}{*}{ Source nutrients } & $\mathrm{Si}(\mathrm{OH})_{4}, \mu \mathrm{M}$ & 7.5 & $7.8 \pm 2.31(\mathrm{n}=10)$ \\
\hline & $\mathrm{NO}_{3}, \mu \mathrm{M}$ & 12.0 & $14.1 \pm 1.79(\mathrm{n}=10)$ \\
\hline \multirow[t]{2}{*}{ Surface nutrients } & $\mathrm{Si}(\mathrm{OH})_{4}, \mu \mathrm{M}$ & 2.70 & $2.17 \pm 0.61(\mathrm{n}=10)$ \\
\hline & $\mathrm{NO}_{3}, \mu \mathrm{M}$ & 6.08 & $6.34 \pm 1.24(\mathrm{n}=35)$ \\
\hline \multirow[t]{6}{*}{$>5 \mu \mathrm{m}$ fraction } & $\rho \mathrm{NO}_{3}, \mu \mathrm{mol} \mathrm{L}-1 \mathrm{~d}^{-1}$ & 0.032 & $0.067 \pm 0.022(\mathrm{n}=9)$ \\
\hline & $\rho \mathrm{NH}_{4}, \mu \mathrm{mol} \mathrm{L}{ }^{-1} \mathrm{~d}^{-1}$ & 0.021 & $0.045 \pm 0.016(\mathrm{n}=9)$ \\
\hline & $\mathrm{PON}, \mu \mathrm{mol} \mathrm{L}-1$ & 0.089 & $0.27 \pm 0.06(\mathrm{n}=9)$ \\
\hline & f-ratio & 0.6 & 0.6 \\
\hline & $\rho \mathrm{C}, \mu \mathrm{mol} \mathrm{L}{ }^{-1} \mathrm{~d}^{-1}$ & & $1.320 \pm 0.227(\mathrm{n}=9)$ \\
\hline & $\mathrm{POC}, \mu \mathrm{mol} \mathrm{L}^{-1}$ & & $2.90 \pm 0.33(\mathrm{n}=9)$ \\
\hline \multirow[t]{6}{*}{$<5 \mu \mathrm{m}$ fraction } & $\rho \mathrm{NO}_{3}, \mu \mathrm{mol} \mathrm{L}{ }^{-1} \mathrm{~d}^{-1}$ & 0.044 & $0.018 \pm 0.024(\mathrm{n}=9)$ \\
\hline & $\rho \mathrm{NH}_{4}, \mu \mathrm{mol} \mathrm{L}{ }^{-1} \mathrm{~d}^{-1}$ & 0.151 & $0.057 \pm 0.026(\mathrm{n}=9)$ \\
\hline & $\mathrm{PON}, \mu \mathrm{mol} \mathrm{L}-1$ & 0.178 & $0.401 \pm 151(\mathrm{n}=9)$ \\
\hline & f-ratio & 0.22 & 0.13 \\
\hline & $\rho \mathrm{C}, \mu \mathrm{mol} \mathrm{L} \mathrm{L}^{-1} \mathrm{~d}^{-1}$ & & $0.609 \pm 0.504(\mathrm{n}=9)$ \\
\hline & POC, $\mu \mathrm{mol} \mathrm{L}^{-1}$ & & $7.98 \pm 1.66(\mathrm{n}=9)$ \\
\hline
\end{tabular}
From $140^{\circ} \mathrm{W}$ to $110^{\circ} \mathrm{W}$ Along the Equator 
a

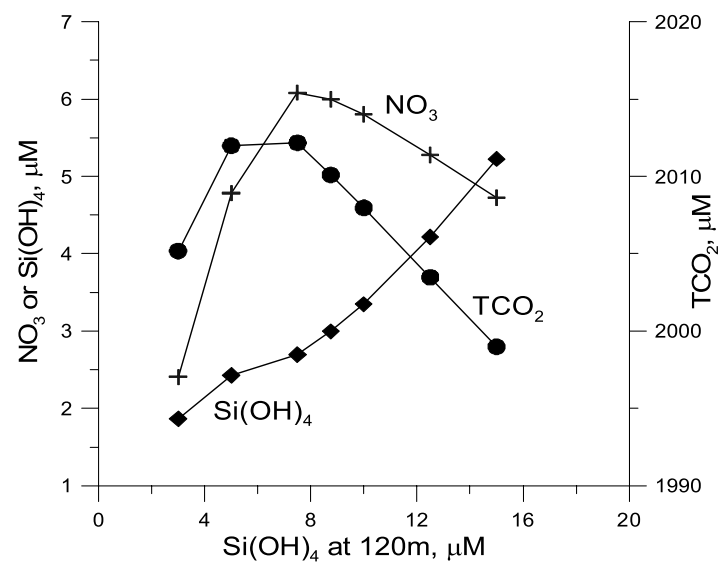

b

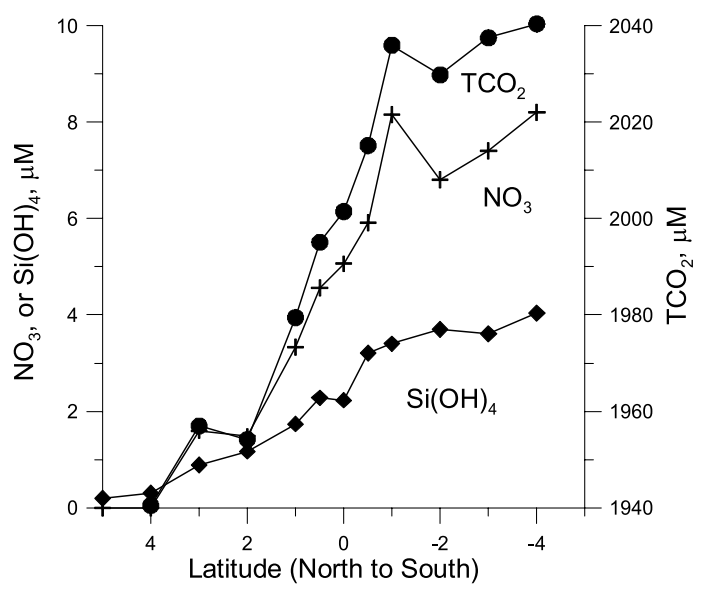

C

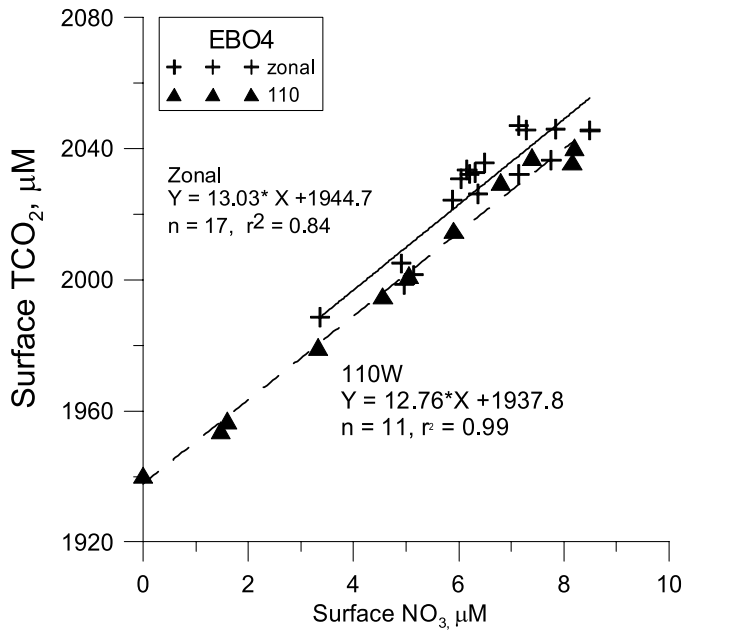

Figure 7. (a) CoSINE model predictions of surface $\mathrm{NO}_{3}$, $\mu \mathrm{M}, \mathrm{Si}(\mathrm{OH})_{4}, \mu \mathrm{M}$, and $\mathrm{TCO}_{2}, \mu \mathrm{M}$, made using different upwelling-source concentrations of $\mathrm{Si}(\mathrm{OH})_{4}$; (b) meridional surface $\mathrm{NO}_{3}, \mu \mathrm{M}, \mathrm{Si}(\mathrm{OH})_{4}, \mu \mathrm{M}$, and $\mathrm{TCO}_{2}, \mu \mathrm{M}$, measured at $110^{\circ} \mathrm{W}$ during EB04; and (c) surface $\mathrm{TCO}_{2}, \mu \mathrm{M}$ versus $\mathrm{NO}_{3}, \mu \mathrm{M}$, measure during zonal and meridional sections sampled during EB04.

calculated by first calculating the value of $\operatorname{Vmax}_{\mathrm{Si}}$ as a function of $\mathrm{Fe}$,

$$
\operatorname{Vmax}_{\mathrm{Si}}=0.5 * \mathrm{Fe},
$$

and inserting this value into the Michaelis-Menten equation organized to give the ambient $\mathrm{Si}(\mathrm{OH})_{4}$ concentration for a constant value of $\mathrm{V}_{\mathrm{Si}}$. (The constant $\mathrm{V}_{\mathrm{Si}}$ is the consequence of top down, grazing control of the loss rate and so controlling the growth rate of the diatoms.)

$$
\mathrm{Si}(\mathrm{OH})_{4}=\mathrm{V}_{\mathrm{Si}} * \mathrm{~K}_{\mathrm{Si}} /\left(\mathrm{Vmax}_{\mathrm{Si}}-\mathrm{V}_{\mathrm{Si}}\right) .
$$

This value of $\mathrm{Si}(\mathrm{OH})_{4}$ is then used as the operating point $\mathrm{Si}(\mathrm{OH})_{4}$ in equation (2) above to obtain the BSi (diatom biomass) that can be sustained. Values of source $\mathrm{Si}(\mathrm{OH})_{4}$ $(7.8 \mu \mathrm{M})$ and euphotic zone depth $(114 \mathrm{~m})$ were taken from EB04. The calculated effect that variations in $\mathrm{Fe}$ over the range 0 to $0.2 \mathrm{nM}$ (through its effect on $\mathrm{Vmax}_{\mathrm{Si}}$ ) have on surface $\mathrm{Si}(\mathrm{OH})_{4}$ and $\mathrm{BSi}$ are shown in Figure 8. Increasing Fe results in decreased surface $\mathrm{Si}(\mathrm{OH})_{4}$ and consequently more $\mathrm{Si}(\mathrm{OH})_{4}$ is converted to $\mathrm{BSi}$ with a total range of about 0.02 to $0.06 \mu \mathrm{mol} \mathrm{L}^{-1}$. Values of Fe below $0.05 \mathrm{nM}$ result in washout of the diatom population as the $\operatorname{Vmax}_{\mathrm{Si}}$ is lower than the ambient grazing loss rate $\left(\mathrm{V}_{\mathrm{Si}}\right)$. These results help explain why high concentrations of chlorophyll are never seen on the equator. The picoplankton populations are always quite low and not very variable. Any large changes in phytoplankton biomass as chlorophyll (illustrated above as BSi) would have to occur from increased number of diatoms but they only have a very limited capacity for biomass increase due to the fundamental $\mathrm{Si}(\mathrm{OH})_{4}$ limitation of this upwelling system.

[19] Three mysteries about the equatorial Pacific upwelling ecosystem should be considered solved by this modeling and data study, (1) the low chlorophyll with "high" nutrients, (2) the relatively low and invariant primary productivity and (3) high surface $\mathrm{CO}_{2}$. A combination of the low ratio of $\mathrm{Si}(\mathrm{OH})_{4}$ to $\mathrm{NO}_{3}$ in the EUZ source water, the relatively low concentrations of these two nutrients in the equatorial undercurrent and continuous upwelling sets up a $\mathrm{Si}(\mathrm{OH})_{4}$ limited chemostat-like environment for diatoms. This imposes strong limits on diatom biomass and productivity. Diatoms reduce the source $\mathrm{NO}_{3}$ concentration only to the extent of available $\mathrm{Si}(\mathrm{OH})_{4}$ and so leave $\mathrm{NO}_{3}$ and $\mathrm{CO}_{2}$ in surplus at the ocean surface. A background population of picoplankton grow on a diet of $\mathrm{NH}_{4}$ produced through grazing and originally entering the ecosystem through diatom uptake of $\mathrm{NO}_{3}$. Under these conditions, equatorial new production can only increase through (1) a change in the $\mathrm{Si}(\mathrm{OH})_{4}$ uptake kinetics, for example, through addition or subtraction of Fe; (2) through increased $\mathrm{Si}(\mathrm{OH})_{4}$ concentration in the EUC source water, likely to occur only on long, even geological timescales or (3) through increased upwelling. However, additions of Fe would only increase production by a limited amount, determined by the surface $\mathrm{Si}(\mathrm{OH})_{4}$ available. Only increased upwelling is likely to result in significant effects on new production. Such upwelling of nutrients may occur with the passage of tropical instability waves, as was observed during cruises to the equatorial Pacific [e.g., Dugdale et al., 2002; Strutton et al., 2001], where enhanced productivity was measured.

[20] The paradox is that the large-celled population may also contain taxa other than diatoms such as dinoflagellates and haptophytes [Chavez et al., 1996; Mackey et al., 2002; 


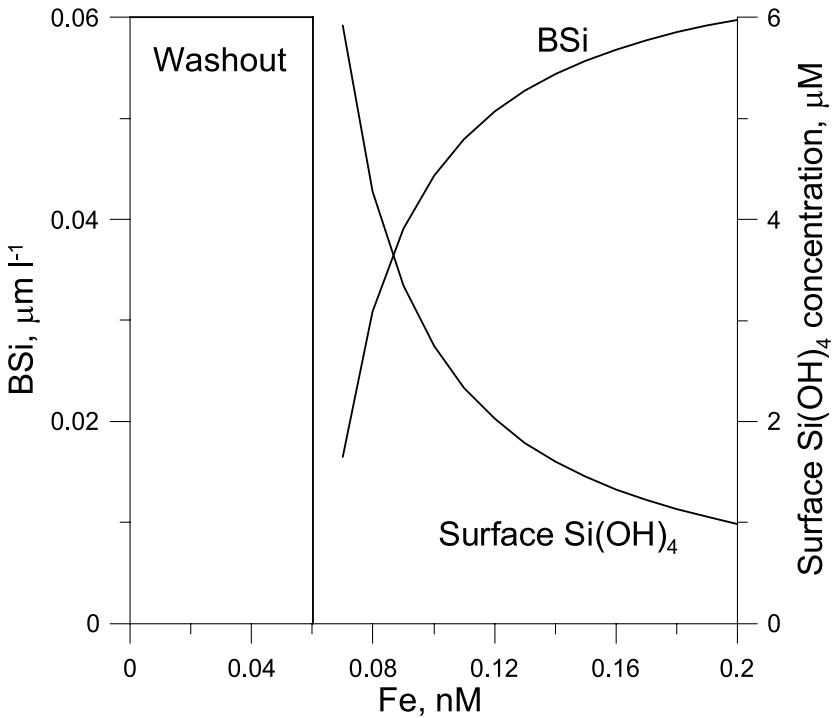

Figure 8. Effect of increasing Fe concentration on BSi accumulation, modeled using the Michaelis-Menten relationship between $\mathrm{Fe}$ and $\mathrm{Vmax}_{\mathrm{Si}}$.

Brown et al., 2003]. Diatoms may comprise as little as $15 \%$ of the $>5 \mu \mathrm{m}$ fraction in the western equatorial Pacific [Le Borgne and Landry, 2003]. Diatoms form a larger proportion of the $>5 \mu \mathrm{m}$ fraction in the EUZ [Iriarte and Fryxell, 1995; Bidigare and Ondrusek, 1996] than in the warm pool, although Le Borgne et al. [2002b] report that there is no difference in the phytoplankton size structure in these two regions. However indications of nondiatom processes in the $>5 \mu \mathrm{m}$ fraction can be seen in that the measured $\mathrm{NH}_{4}$ and $\mathrm{NO}_{3}$ uptake of larger cells during EB04 was greater than predicted by the CoSINE model by a factor of 2 (Table 1). The measured PON during EB04 was greater than modeled by a factor of about 3, likely the result of nondiatom elements. Possibly the dinoflagellates and haptophytes seen in other studies [Brown et al., 2003] were taking up $\mathrm{NH}_{4}$ and $\mathrm{NO}_{3}$ in the same proportion as predicted for the diatoms, 0.6 (Table 1) by the CoSINE model. However, that raises the old question of why so much $\mathrm{NO}_{3}$ remains in the surface waters of the EUZ if these non-Si(OH $)_{4}$ users are able to use $\mathrm{NO}_{3}$. The wealth of data produced by the EB04 and EB05 Biocomplexity cruises should help to resolve the question of the relative importance of different phytoplankton groups in new production in EUZ. However, the main thesis of this communication is that EB04 data and the CoSINE model both support the conclusion that the majority of new production is carried out by the $>5 \mu \mathrm{m}$ sized phytoplankton population. The similarity between modeled and measured results indicates that the diatom component of this fraction is likely to make an important impact on the LSi-HNLC condition of the EUZ through their effects on $\mathrm{NO}_{3}, \mathrm{Si}(\mathrm{OH})_{4}$ and $\mathrm{TCO}_{2}$ fluxes.

[21] Acknowledgments. This research was supported by the National Science Foundation (JGOFS SMP: OCE 98-02060 and BioComplexity OCE 03-22074). We are grateful to all the members of the Dugdale/ Wilkerson laboratory at RTC, especially V. Hogue, A. Marchi, and A. Parker, and the scientists involved with the EB04 cruise for useful discussions, and the assistance of the crew of the R/V Roger Revelle.

\section{References}

Barber, R. T. (1992), Introduction to the WEC 88 cruise-An investigation into why the equator is not greener, J. Geophys. Res., 97, 609-610.

Bidigare, R. R., and M. E. Ondrusek (1996), Spatial and temporal variability of phytoplankton pigment distributions in the central equatorial Pacific Ocean, Deep Sea Res., Part II, 43, 809-833.

Bran Luebbe AutoAnalyzer Applications (1999), Silicate in water and seawater, AutoAnalyzer Method G-177-96, Bran Luebbe, Buffalo Grove, Ill.

Brown, S. L., M. R. Landry, J. Neveux, and C. Dupouy (2003), Microbial community abundance and biomass along a $180^{\circ}$ transect in the equatorial Pacific during an El Niño-Southern Oscillation cold phase, J. Geophys. Res., 108(C12), 8139, doi:10.1029/2001JC000817.

Brzezinski, M. A. (1985), The Si:C:N ratio of marine diatoms: Interspecific variability and the effect of some environmental variables, J. Phycol., 21, $347-357$.

Chai, F., S. T. Lindley, and R. T. Barber (1996), Origin and maintenance of a high nitrate condition in the equatorial Pacific, Deep Sea Res., Part II, 43, $1031-1064$

Chai, F., R. C. Dugdale, T. H. Peng, F. P. Wilkerson, and R. T. Barber (2002), One dimensional ecosystem model of the equatorial Pacific upwelling system, Part 1: Model development and silicon and nitrogen cycle, Deep Sea Res., Part II, 49, 2713-2745.

Chavez, F. P., K. R. Buck, S. K. Service, J. Newton, and R. T. Barber (1996), Phytoplankton variability in the eastern and central tropical Pacific, Deep Sea Res., Part II, 43, 835-870.

Cullen, J. J., M. R. Lewis, C. O. Davis, and R. T. Barber (1992), Photosynthetic characteristics and estimated growth rates indicate grazing is the proximate control of primary production in the equatorial Pacific, J. Geophys. Res. 97, 639-654.

Dugdale, R. C. (1967), Nutrient limitation in the Sea; Dynamics, identification, and significance, Limnol. Oceanogr., 12, 685-695.

Dugdale, R. C., and F. P. Wilkerson (1986), The use of N-15 to measure nitrogen uptake in eutrophic oceans-Experimental considerations, Limnol. Oceanogr., 31, 673-689.

Dugdale, R. C., and F. P. Wilkerson (1992), Nutrient limitation of new production, in Primary Productivity and Biogeochemical Cycles in the Sea, edited by P.G. Falkowski and A. D. Woodheads, p. 107-122, Springer, New York.

Dugdale, R. C., and F. P. Wilkerson (1998), Silicate regulation of new production in the equatorial Pacific upwelling, Nature, 391, 270-273.

Dugdale, R. C., F. P. Wilkerson, R. T. Barber, and F. P. Chavez (1992), Estimating new production in the equatorial Pacific Ocean at $150^{\circ} \mathrm{W}$, J. Geophys. Res., 97, 681-686.

Dugdale, R. C., F. P. Wilkerson, and H. J. Minas (1995), The role of a silicate pump in driving new production, Deep Sea Res., Part I, 42, 697 719 .

Dugdale, R. C., R. T. Barber, F. Chai, T. H. Peng, and F. P. Wilkerson (2002), One dimensional ecosystem model of the equatorial Pacific upwelling system, Part II: Sensitivity analysis and comparison with JGOFS EqPac Data, Deep Sea Res., Part II, 49, 2747-2768.

Dugdale, R. C., M. Lyle, F. P. Wilkerson, F. Chai, R. T. Barber, and T.-H. Peng (2004), Influence of equatorial diatom processes on $\mathrm{Si}$ deposition and atmospheric $\mathrm{CO}_{2}$ cycles at glacial/interglacial timescales, Paleoceanography, 19, PA3011, doi:10.1029/2003PA000929.

Feely, R. A., et al. (2002), Seasonal and interannual variability of $\mathrm{CO}_{2}$ in the equatorial Pacific, Deep Sea Res., Part II, 49, 2443-2469.

Frost, B. W., and N. C. Franzen (1992), Grazing and iron limitation in the control of phytoplankton stock and nutrient concentration: A chemostat analogue of the Pacific equatorial upwelling zone, Mar. Ecol. Prog. Ser, $83,291-303$.

Iriarte, J. L., and G. A. Fryxell (1995), Micro-phytoplankton at the equatorial Pacific $\left(140^{\circ} \mathrm{W}\right)$ during the JGOFS EqPac time series studies: March to April 1992, Deep Sea Res., Part II, 42, 559-584.

$\mathrm{Ku}$, T.-L., S. Luo, M. Kusakabe, and J. K. B. Bishop (1995), ${ }^{228}$ Ra-derived nutrient budgets in the upper equatorial Pacific and the role of gnewh silicate in limiting productivity, Deep Sea Res., Part II, 42, 479-497.

Le Borgne, R., and M. R. Landry (2003), EBENE: A JGOFS investigation of plankton variability and trophic interactions in the equatorial Pacific $\left(180^{\circ}\right)$, J. Geophys. Res., 108(12), 8136, doi:10.1029/2001JC001252.

Le Borgne, R., R. A. Feely, and D. J. Mackey (2002a), The Equatorial Pacific JGOFS synthesis, Deep Sea Res., Part II, 49, 2425-2823.

Le Borgne, R., R. T. Barber, T. Delcroix, H. Inoue, D. J. Mackey, and M. Rodier (2002b), Pacific warm pool and divergence: Temporal and zonal variations on the equator and their effects on the biological pump, Deep Sea Res., Part II, 49, 2471-2512. 
Leynaert, A., P. Treguer, C. Lancelot, and M. Rodier (2001), Silicon limitation of biogenic silicon production in the equatorial Pacific, Deep Sea Res., Part I, 48, 639-660.

Leynaert, A., E. Bucciarelli, P. Claquin, R. C. Dugdale, V. Martin-Jézéquel, P. Pondaven, and O. Ragueneau (2004), Effect of iron deficiency on diatom cell size and silicic acid uptake kinetics, Limnol. Oceanogr., 49, $1134-1143$

Mackey, D. J., J. Blanchot, H. W. Higgins, and J. Neveux (2002), Phytoplankton abundances and community structure in the equatorial Pacific, Deep Sea Res., Part II, 49, 2561-2582.

Minas, H. J., and M. Minas (1992), Net community production in "high nutrient-low chlorophyll" waters of the tropical and Antarctic Oceans: Grazing vs. iron hypothesis, Oceanol. Acta, 15, 145-162.

Solorzano, L. (1969), Determination of ammonia in natural waters by the phenolhypochlorite method, Limnol. Oceanogr., 14, 799-801.

Strutton, P. G., J. P. Ryan, and F. P. Chavez (2001), Enhanced chlorophyll associated with tropical instability waves in the equatorial Pacific, Geophys. Res. Lett., 28, 2005-2008.
Takahashi, T., et al. (2002), Global sea-air $\mathrm{CO}_{2}$ ?ux based on climatological surface ocean $\mathrm{pCO}_{2}$, and seasonal biological and temperature effects, Deep Sea Res., Part II, 49, 1601-1622.

Whitledge, T. E., S. Malloy, C. J. Patton, and C. D. Wirick (1981), Automated nutrient analysis in seawater, Tech. Rep. BNL 51398, 226 pp., Brookhaven Natl. Lab., Upton, New York.

Wilkerson, F. P., and R. C. Dugdale (1992), Measurements of nitrogen productivity in the equatorial Pacific, J. Geophys. Res., 97, 669-679.

F. Chai, School of Marine Science, University of Maine, 5471 Libby Hall, Orono, ME 04469-5741, USA.

R. C. Dugdale and F. P. Wilkerson, Romberg Tiburon Center, San Francisco State University, 3152 Paradise Drive, Tiburon, CA 94920, USA. (rdugdale@sfsu.edu)

R. Feely, Pacific Marine Environmental Laboratory, National Oceanographic and Atmospheric Administration, 7600 Sand Point Way, NE Seattle, WA 98115, USA 